ENTREPRENEURSHIP AND SUSTAINABILITY ISSUES

ISSN 2345-0282 (online) http://jssidoi.org/jesi/

2020 Volume 7 Number 4 (June)

http://doi.org/10.9770/jesi.2020.7.4(26)

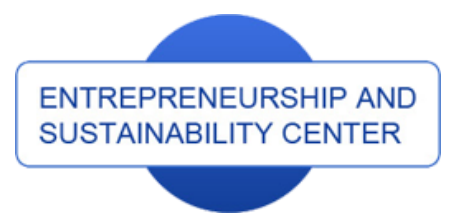

Publisher

http://jssidoi.org/esc/home
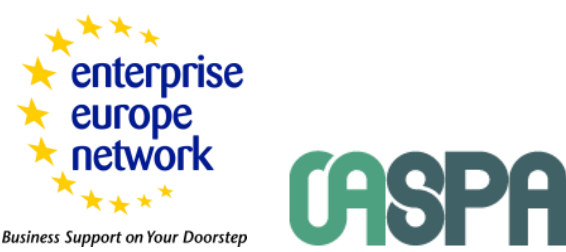

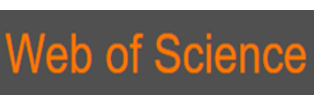

Clarivate

Analytics

\title{
RELEVANCE AND SOCIAL RESPONSIBILITY OF SUSTAINABLE UNIVERSITY ORGANIZATIONS: ANALYSIS FROM THE PERSPECTIVE OF ENDOGENOUS CAPACITIES
}

\section{Judith J. Hernández García de Velazco ${ }^{1}$, Rafael Ravina Ripoll ${ }^{2}$, Ana Cecilia Chumaceiro Hernandez ${ }^{3}$}

\author{
${ }^{1}$ Department of Law and Political Sciences of La Universidad de la Costa, Street 58 \#55-66 \\ Barranquilla, Colombia \\ ${ }^{2}$ Faculty of Economics and Business, Universidad de Cadiz, Andalucia, Spain \\ ${ }^{3}$ Business Sciences Department of La Universidad de la Costa, Street 58 \#55-66 \\ Barranquilla, Colombia \\ E-mails : ${ }^{1}$ lasanas23@gmail.com,jhernand86@cuc.edu.co $;{ }^{2}$ rafael.ravina@uca.es $;{ }^{3}$ anachuma@gmail.com, \\ 3achumace@cuc.edu.co
}

Received 20 October 2019; accepted 15 April 2020; published 30 June 2020

\begin{abstract}
The university social relevance is the effective management of the academic functions in a committed way, from which it analyzes, studies, and investigates the problems, needs, requirements of the social environment to identify, characterize, rank them. And a model social action to the research, teaching, extension, and training of professionals, consistent with social needs, linked to the realities of the various contexts of human performance that neo university organizations, rescuing sustainability with human development and socioeconomic, involving the creative potentials and indigenous innovations of society. To coexistence between community and university in favor of endogenous growth is required, conceived as the leverage from the social and organizational strengths of the human conglomerate in reference, which promote; quality of life and sustainable human progress. Consequently, the purpose of this dissertation is limited to carrying out an analysis of the relevance and social responsibility of sustainable university organizations from the endogenous perspective. From the qualitative, interpretive, and hermeneutical paradigm, the categories of analysis are reviewed, to conclude; that the university theoretically approaches endogenous development. However, it is necessary to generate links of structural- organizational configuration within the educational institutions that involve processes related to their sustainability over time and their impacts.
\end{abstract}

Keywords: University social relevance; university social responsibility; endogenous development; organization; sustainability

Reference to this paper should be made as follows: Hernández de Velazco, J.J., Ravina Ripoll, R., Chumaceiro Hernandez, A.C. 2020. Relevance and social responsibility of sustainable university organizations: analysis from the perspective of endogenous capacities. Entrepreneurship and Sustainability Issues, 7(4), 2967-2977. https://doi.org/10.9770/jesi.2020.7.4(26)

JEL Classifications: I23, I25 


\section{ENTREPRENEURSHIP AND SUSTAINABILITY ISSUES}

ISSN 2345-0282 (online) http://jssidoi.org/jesi/

2020 Volume 7 Number 4 (June)

http://doi.org/10.9770/jesi.2020.7.4(26)

\section{Introduction}

The 21st century has been marked by multiple scenarios and accelerated transformations in the political, social, cultural, and technological development. The economy also has transmuted toward new forms of globalized production, exchange, and extra connection-borders of markets, as attempted regional blocs, such as in the case of Latin America and their experiences.

It is a century marked by great contradictions, where technology, informatics, the rearrangement socio-economic and political demand of human capital of large social formation in which the knowledge component is a development priority for any society, but in some countries of the region access to higher education is mediated by economic factors that limit the inclusion of broad sectors of the population.

Unfortunately, the development is not a similar mechanism, expeditious and equitable access for developing countries, continues to produce inequality, even in the same geographical spaces that have created a certain degree of progress, but without achieving the insertion of all human conglomerates, generating increasing economic differences, labor, even in priority areas such as health and education, increasing marginalization and the gap between rich and poor.

Moreover, in countries of most significant progress, such transformations does not escape of claims and conflicts that are identified among others by; an unfair distribution of educational opportunities, exclusion from the labor market a product of technological and organizational improvements, the production of knowledge in universities that are not transmitted to the productive apparatus, the curricular offerings that do not conform to the professional needs, and indiscriminate privatization of universities.

The product of these dynamics that inhibit an inclusive development have proposed specific operational guidelines for university institutions conform to these changes as are: expansion of tuition, diversification of funding sources, organizational restructuring, planning, controls and accountability, linking and responsibility with the social environment; updating of knowledge and renewal of skills, as well as the definitive establishment of the action shared between university, the productive apparatus at local, regional and national levels, with the centers of public and private decision.

Additionally, in the last decade, have proposed models of a university such as the university social relevance that are associated with its commitment to social responsibility and organizational and with its external linkage, as explained by Beltran-Llavador et al. (2014). The determination of the university requires its ability and effectiveness in responding to the needs of transformation of the society where it is immersed, and that the organization also feel and be part of that equal society.

That is to say, that the relevance and social responsibility are unavoidable in the face of the collective needs that must be met equitably, plural, and according to the requirements and human realities, rescuing sustainability, appropriating harmoniously of socio-economic development from natural resources, materials, technicians, as well as the creative potentialities, innovative, indigenous peoples, of society. By requiring a coexistence between Society and the University of endogenous development, but strictly sustainable.

Understanding by endogenous development; the leverage from the strengths and opportunities of economic, social, cultural, political, of the human conglomerate in reference, and conducive to quality of life, human progress, and sustainable development. In the specific case of the university organizations, it is the sum of the internal efforts to sustain in time their strengths and opportunities in the service of the externalities that interact in pro of progress, general well-being of even the organizational and social happiness. 


\section{ENTREPRENEURSHIP AND SUSTAINABILITY ISSUES}

ISSN 2345-0282 (online) http://jssidoi.org/jesi/

2020 Volume 7 Number 4 (June)

http://doi.org/10.9770/jesi.2020.7.4(26)

In this order of ideas, from the qualitative paradigm based on the hermeneutic interpretive analysis-, review of these themes or categories related to the management within different organizations, in the understanding of an endogenous perspective for sustainable institutions of higher education as a social process, as Glaser (1992), applying a methodology for analysis, to generate an inductive theory on a substantive area, in this specific case, it is made a review of critical concepts that are interrelated to interpret as from the relevance and responsibility University is can boost sustainable educational organizations with endogenous perspective.

These categories of analysis emerge in the process of construction in the observation, because qualitative research is, searches for the ideographic concepts to understand social behavior. This concern is textually to describe and analyze the social fact from the features determinants (Guardian-Fernández, 2007; Bonilla-Castro and Rodriguez, 2005). As a result, the epistemological perspective of this dissertation is the interpretive paradigm, because the explanation of the social life and the world, related to the categories in reference, it is also of hermeneutic character from its position of theoretical reflection.

The categories analyzed has a meaning emerged from the literature review conducted, segmented for the study of the social relevance of the university organizations sustainable from the endogenous perspective, which makes it possible to interpret university social responsibility as a strategic process in conjunction with the organizational potential of the context and the persistence over time, which showcases the importance of the university as an organization with socio-economic ends and means for the development and general well-being.

\section{Development. Reviewing and analyzing categories - relevance and university social responsibility}

When you mention the significant transformations in which has been wrapped up the 21 st century we are talking about both the universalization of democracy as the globalization of trade, the market, competence standards, human development, sustainability, quality of life, all of which are subjects that require personal knowledge, group and national to face its challenges, because of this, your comprehension, depends on the feasibility of economic, political, social, cultural, human, in many countries.

One of the critical elements to reinsert favorably in this new scenario and radical change is to raise the competitive level of educational systems and the preparation of high-level human resources, which also means improving the capacity of academic cooperation, scientific, technological development.

For Beltran-Llavador et al. (2014), the university has always developed his work from a social conscience, in an evolution of its orientations; has had moments oriented toward the production of knowledge exclusively, moving in time with the training of professionals tailored to the needs of society, up to the present with the resurgence of the debate about the social responsibility of the university institution to recognize that higher education, as a public good, it is the responsibility of all parties concerned.

Some researchers, such as García (2000), define a concept known as university college with social relevance, in which it analyzes, studies, and researches the priority problems of their social environment to identify, prioritize, propose and participate in the feasible solutions that are derived. In this sense, she remarks García; the university functions: teaching, research, and extension, must be integrated with the essential mission of the university: its social service. The sectors state political, socio-cultural, and economical.

This university-society relationship as regards the social relevance, there arises the need to insert the organization within a framework of globalization, competitive characteristic of today's world, but that does not imply leaving aside the local and regional levels, but combine the universal of knowledge and its application to the particular context of a community, society, and country. 


\section{ENTREPRENEURSHIP AND SUSTAINABILITY ISSUES}

ISSN 2345-0282 (online) http://jssidoi.org/jesi/

2020 Volume 7 Number 4 (June)

http://doi.org/10.9770/jesi.2020.7.4(26)

These new phenomena, such as post-technological, are producing models of university, virtual university, corporate university entrepreneurial university, each with different kinds of linkages with the environment.

The relevance that is also referred to the social responsibility of the university, it is assumed as the kinks in this dissertation, in the search for solutions to social problems related to the world of work, production, citizens' associations, in general, in a linear perspective to the surroundings contextualizes and their needs, resources, potential, from historical dimensions and space, and foresight, the latter, in recurrence to the sustainability both human and organizational performance these educational institutions.

Inline, expresses Vallaeys (2018), "Therefore, there is an intrinsic relationship between ethics of responsibility, definition of social responsibility in terms of responsibility for the impacts and duty of vigilance and interorganizational association to resolve the problems of justice and sustainability of social set." In general, corporate social responsibility is endeavoring to improve their immediate environment, and that of the community with which it relates when makes contributions for the benefit of her performs or participates in social activities (Palomino and Lopez, 2019; Paz Marcano, Sierra Daza \& López Juvinao, 2019)

Therefore, the responsibility of universities necessarily refers to the treatment of its social function to the interest of a scenario defined. Must be the result of broad agreements within the university and beyond with the actors involved in its socio-economic environment, to consolidate the real development according to the realities and the resolution of the problems in the field in which is immersed, evidently from a perspective of endogenous (category also analysis).

However, university models in Latin America have not exceeded specific criteria which makes it difficult for them to take on the challenge of relevance, because it is defined by the demands of the political orientations of governments, the requirements from international agencies, exogenous macroeconomic policies, and the own dynamics of political subjection-participatory versus the power groups in each country.

In universities, in general, continues a tradition of training and research outside the environment and located in the methodological positivism, which produces and accumulates knowledge in a disjointed and utilitarian, preventing a contextualized approach to provide an overall perspective capable of linking the concrete projects with development problems, in such a way that explicitly assume its incidence in the local, regional and national levels.

As a result of the above Treaty, the university organizations should articulate with the State, government policies, and the productive sector, their science structures toward the new academic reality, to the era of globalization, the maintenance of democracy, and its commitment to sustainable social development. How to Express Chumaceiro, Hernandez, and Chirinos (2016: 58), education for sustainable development: "The latest studies on the development processes efficiently highlighted the importance of human and social capital in successful experiences. That is why the fundamental pillar for sustainable development lies in the training of professionals with social development approach. In this regard, the urgency for the formation centered on a humanist vision, social, economic, and politically sustainable is imminent"

It is coinciding with Vallaeys (2016) who proposes, a socially responsible university with a project of coexistence, anchored in its territory, or, on the contrary of the multinational model of the massive knowledge unanchored. 


\section{ENTREPRENEURSHIP AND SUSTAINABILITY ISSUES}

ISSN 2345-0282 (online) http://jssidoi.org/jesi/

2020 Volume 7 Number 4 (June)

http://doi.org/10.9770/jesi.2020.7.4(26)

University Social Responsibility, involves the full commitment in the formation of competencies consistent from ethics, contribution to peace, the defense of social values, democratic and human rights (Martínez-Usarralde, 2017; Chen, Nasongkhla \& Donaldson, 2015; Girdzijauskaite et al., 2019).

In summary and interpreting, the university has a fundamental role with the actors involved in strengthening the development and promote the general welfare, as organizations in its structure include such essential elements; the academic work, promotion, humanistic, community, environment, and sustainable development, from scientific approaches multi, inter and transdisciplinary, and where strategic alliances between civil society, State, private sector and academia, are essential to ensure a decent quality of life and autonomously growing for the majority of the population, all within the respect of cultural differences.

\section{Sustainable organizations and approximation to endogenous development}

Sustainable development in a first approximation generalist is defined as development that meets the needs of the present without compromising the ability of future generations to meet their own needs. (Brundtland, 1987, 41). However, its conceptualization and therefore its application evolved and continues to grow according to the historical dynamics and also from the various epistemological perspectives of their study, in that order of ideas, Sachs (2015) explained that with time, the definition of sustainable development evolved toward a more practical approach, with less emphasis on inter-generational needs and more holistic approach, with direct connections to economic growth, social inclusion, and sustainability.

Considering the economic development, are entered three fundamental dimensions; economic, social and environmental, which allows you to extrapolate from this point of view here raised, the intervention of actors and institutions that are made stewards of sustainable development and sustainability directly; The State, governments, the private sector, citizenship, the organizations with different objects and scope, including universities as critical organs of the development of competencies that contribute to the socio-economic wellbeing.

Bernal and Rivera (2011), since such a configuration, pose that education has become a strategy for the sustainable development of nations. As a result, humanity and the states recognize the role of the university; therefore, allow your activity generator and disseminator of scientific knowledge.

The university as an organization must strive to ensure sustainability, but understanding, according to Largacha, Pinzón, and León (2015), that the organizational sustainability, not only is subject to processes (efficiency, efficacy) but considers the social aspects that include equality, fair treatment, better opportunities for its employees and different partners to improve processes in search of sustainability.

Then, it is assumed that the university organizations have to focus on all aspects of economic, social, and sustainability of development. This development, according to Boisier (2004), depends on four large blocks of factors: economic growth, collective mentality, the endogenous potential latent in all territory, and the set of subsystems that define the complexity of the region and that under certain conditions allow for development.

It introduces the element of endogenous development, seen from the realization of growth and well-being according to the resources and human potential, environmental, techniques that are confined to the immediate sphere of action.

More specifically, for this dissertation, endogenous development is defined by Vázquez-Barquero (1999), as a strategy for action, to undertake the transformations and economic changes in the framework of globalization. Each community has its identity, its historical past, its way of exploiting the ecosystem, that is to say, has its 


\section{ENTREPRENEURSHIP AND SUSTAINABILITY ISSUES}

ISSN 2345-0282 (online) http://jssidoi.org/jesi/

2020 Volume 7 Number 4 (June)

http://doi.org/10.9770/jesi.2020.7.4(26)

mechanisms of action, its mode of production. It is an authentic approach to development, which is characterized by a particular way of organizing their own space.

According to Marin, Atencio, and Hernández (2009: 75), The development it does no one from an outside space, makes it the man in their midst, from their individuality and in your sociability, that is to say from the same. The configuration of this alternative space with endogenous potential must be designed by the same agents involved. It is the participatory design as a critical element in the construction of a society inside. Therefore, to participate in the design, as an essential step, is to stimulate decision-making and respect for the values of each group.

The object of these autonomous spaces is a widespread habitat from a complex perspective and integral, historical, and social reality, addressing the different dimensions, which mentions Boisier (2001), individual, family, group, community, local, regional and global levels.

It is definitive that the endogenous development in a production context, implies sustainability as an ecological purpose and systemic approach, in the sense of the energy-saving and avoid excessive consumption, agreeing with Pereira (2016), from a dynamic sense, as the whole set of human activities aimed to prevent the affectation, alteration, or put at risk the existence of life itself.

Endogenous development rescues in its essence the reality, environment, experiences, abilities, the communities, to achieve progress and structural independence, as Vázquez Barquero (1999), would continue to the formation of a process of entrepreneurship and innovation, for which the territory is not a passive recipient of the strategies, interests, big companies, and external organizations, but from its plan that allows you to influence local economic dynamics.

In summary, as reviewed and analyzed, endogenous development assumed as leveraging strengths economic, social, cultural, political, of society, that additionally creates quality of life, human progress, sustainable development, and sustainability. The construction of a prosperous nation must be the result of joint efforts of citizens, State, businesses, communities, universities, with criteria of fairness, responsibility, sustainability, supported in the generation of knowledge, improvements, innovations, products of the ingenuity, creativity, originality, of the widespread knowledge.

\section{Results}

After the review and analysis of the categories, from the hermeneutic method responds to the formulation raised: How from the relevance and responsibility university is can boost sustainable educational organizations with an endogenous perspective?

The organizations or institutions of higher education have had to overcome various problems to improve its functioning, since its formation the socio-historical, political and economic dynamics that have been determined, the approach to the missional functions (teaching, research, extension-social projection, another), until the issue of financing for their sustenance have caused structural differences, even compared to emerging realities of the 21 st century.

In Latin America and the Russian Federation, therefore, it is possible to establish an insufficient level of research on the business environment, the presence of unresolved scientific problems associated with the need to attract all forms of entrepreneurship in the educational system. Thus, it is possible to state an insufficient level of research on the business environment, the presence of unresolved scientific problems associated with the need to attract all forms of entrepreneurship in the education system. (Mutalimov, 2020). 


\section{ENTREPRENEURSHIP AND SUSTAINABILITY ISSUES}

ISSN 2345-0282 (online) http://jssidoi.org/jesi/

2020 Volume 7 Number 4 (June)

http://doi.org/10.9770/jesi.2020.7.4(26)

Historically, the western influence and from other countries have slanted the generation of knowledge in Latin America, the methods driven by favoring the positivist paradigm as a way of doing science marked by the technique, market relations, utilitarianism.

Science and Method built to establish a pattern of consumption, as practice and rationale. A hegemony of broad international interests, with a single perspective, homogeneous, to develop and disseminate the knowledge from a unique vision it submits. The standardization of human life and the loss of the socio-diversity are equally remarkable results, though destructive, and undesirable. The everyday subverted tends to become unique and dependent on the high consumption of Nature, which increases their fragility. The accelerated loss of the sociodiversity appears a race in search of social states of homogeneity and balance. But in terms of life and society, homogenization and stability are equivalent to death. (Sotolongo and Delgado; 2006: 29)

The university organizations in the Region and the world, in response to the demands arising within the institutions, as well as by state regulatory imperatives, international agreements, supranational bodies, have led to the necessary changes, adjusting its management proactively, in the understanding of social responsibility, as expressed in Ketele (2008: 55): "For an institution of higher education, the relevance supposed to register their objectives within a project of society."

In this order of ideas, universities are transformed to achieve effectively play new roles, allowing it transcend its simple historical function of creation, transmission, and preservation of knowledge, toward new activities social, cultural and environmental, which must remain through time (Chumaceiro, Hernández \& Chirinos, 2016).

It must be understood that national development, the generation of wealth and well-being common, is for the citizens in general, reachable from the wisdom and input from all that independence and domestic production drives the sustainable native production and sustainable, strengthens the acquis and inventive popular. Still, it is essential to systematize this knowledge, progress, and innovations. Accordingly, it is necessary to prioritize in fostering a culture to socialize, make visible the widespread consciousness, citizens, community, and the private sector.

As a result, from the universities, it is essential to begin; systematizing, disseminating, these experiences economic, social, contributing to the general development; to agglutinate the generation and creation of knowledge, scientific advances, a product of the particular contributions and collective that can be generated from the citizen spaces, community, society in general, for universities, academics, communities of formal researchers, and the country in general.

A necessary condition for these advances, try the independence of the scientific praxis through break hegemonic schemes, exogenous (of any nature and origin), building, driving theory, and methods arising from the dynamics of national, regional, and local levels.

In tune with Ahumada, Ravina, and Lopez (2018), this would also, one of the goals of the current social responsibility; cultivate an organizational culture where it fosters among its members the ideology and determination that their activity has direct effect in its spatial framework and influence in society.

Agrees with Sachs (2015), that sustainable development also implies a normative approach on the planet, in the sense that it recommends a series of objectives to which the world should aspire. Sustainable development suggests a holistic approach, in the sense that society must simultaneously pursue economic, social, and environmental goals. 


\section{ENTREPRENEURSHIP AND SUSTAINABILITY ISSUES}

ISSN 2345-0282 (online) http://jssidoi.org/jesi/

2020 Volume 7 Number 4 (June)

http://doi.org/10.9770/jesi.2020.7.4(26)

The goals of sustainable development, involve a planetary approach since its creation in the year 2015, with Agenda 2030 sets the model for shared prosperity in a sustainable world so that all people can lead a productive life, vibrant and peaceful in a healthy planet. In the latest report of the objectives of sustainable development highlights the collaboration of actors and institutions such as the university, "a wide range of other actors - international organizations, companies, local authorities, the scientific community, and civil society have become committed to the ODS in such a way that generate great optimism for the next decade." (United Nations, 2019:2). The scope and the ambitions of the new "Agenda 2030" of the global community have grown dramatically, as well with the Millennium Development Goals (SDGS) are duplicated in comparison with the Millennium Development Goals (2000-2015), because it contains almost ten times more objectives and five times more indicators (Voronkova, 2020).

In conclusion, the organizations became permanent to the extent that they adjust their organizational processes, both the productive, technological, and human resources, in a synergetic perspective of the purposes and shared values, in the growth, development, integration, and achieving the common good. In the harmony of interests and general, that make sustainable development in the organization, in this case, to universities in pro of endogenous growth from the philosophy of social responsibility.

\section{Conclusions}

From the universities, the social relevance implies to be recognized in your environment to interact effectively, at the same time that social responsibility requires him to be directly linked to its territoriality, environment, and frameworks for action. The social function of the autonomic educational organizations, in particular the universities, gives it its humanist character of formation for a professional, technical, that it be integrated into society in the fullness of its development, its realization socio-economic and their contributions to society as a whole.

Accordingly, the endogenous development is pushed from these constructions individuals citizens, who engage the local, national, with their contributions and innovations for diverse areas of knowledge and praxis, in perspective with the conservation and sustainability of the system of organizations and resources, both human, as natural, technological and economic. In the harmony of social and productive networks, where people are not another element for the creation but the very makers of inventiveness, of contribution, as subject and object of the realities that intervenes to improve and achieve welfare.

The endogenous development without prejudice against exogenous production, which is always necessary for diversification and scarce resources, it is a question of competitiveness on equal terms, and in the fair recognition of the abilities and skills of the local working population.

The categories treated theoretically, factual in your application in universities demand complex processes, and in the more specific spectrum of endogenous development is further complicated even more, because they require converge on a more inclusive society, equitable, environmentalist, with indicators of human, organizational management effectively in achieving responsible for social welfare and happiness.

Keep as far as possible from the multiple perspective the purpose of endogenous development and their potential in equal opportunities for citizens. Still, respecting the cognitive differences, cultural, training, requires that its structural configuration-organizational fit for the attainment of these purposes.

In this regard, universities as sustainable organizations and national governments in pro of endogenous development, have outstanding tasks, several actions would be in harmony with this paradigm to make relevant university: 


\section{ENTREPRENEURSHIP AND SUSTAINABILITY ISSUES}

ISSN 2345-0282 (online) http://jssidoi.org/jesi/

2020 Volume 7 Number 4 (June)

http://doi.org/10.9770/jesi.2020.7.4(26)

- Promote and generate a public policy that prioritizes the revision of curricular offerings according to the potentialities of production, human socio-economic needs, and expertise, the context of insertion.

- Research an own epistemology and ontology, designed from the problematic socioeconomic, political, and cultural life of the country.

- Leverage the endogenous development from the various public policies of structural character that encourage States and from which the university can be linked properly.

- Take a philosophy of organization-structure-management-action consistent between university and endogenous development, human, sustainable, from the diversity and inclusion.

\section{References}

Ahumada-Tello, Eduardo; Ravina-Ripoll, Rafael; and Lopez-Regalado, Martha (2018). University Social Responsibility. Development of organizational competitiveness from the educational process, 18(3), 1-30. Costa Rica. https://doi.org/10.15517/aie.v18i3.34213

Beltran-Llavador, Joseph, Iñigo-Low, Enrique, \& Mata-Segreda, Alejandrina. (2014). University Social Responsibility, the challenge of its permanent construction. Journal of Higher Education, 5(14), 3-18. http://www.scielo.org.mx/scielo.php?script=sci_arttext\&pid=S2007$\underline{28722014000300001 \& \operatorname{lng}=\mathrm{es} \& \ln \mathrm{ln}=\mathrm{es}}$

Bernal, H. \& Rivera, B. (2011). University Social Responsibility: Contributions to the analysis of a concept. University Social Responsibility. The University Thinking No. 21. Documents. Colombian Association of Universities - ASCUN. ISSN. 0124-3543. Bogotá D.C., March 2011. pp. 7-17. (105). https://plataforma.responsable.net/explorar/pensamiento-universitario-n-21

Boisier, Sergio (2001). The knowledge society, human knowledge, and territorial management. Institute of Regional Development. University of Seville.

Boisier, Sergio. (2004). Endogenous Development: What for? for whom? The humanism in a contemporary interpretation of development. Catholic University of Chile.

Chen, S. A., Nasongkhla, J., \& Donaldson, J. A. (2015). University Social Responsibility (USR): Identifying an ethical foundation within higher education institutions. Turkish Online Journal of Educational Technology, 14(4), 165-172.

https://files.eric.ed.gov/fulltext/EJ1077652.pdf

Chumaceiro Hernández, Ana C.; Hernández García de Velazco, Judith; and Chirinos Norono, Enrique (2016). University Social Responsibility, Sustainable development, and environmental citizenship. Notebooks of RSO. 4(1), 53-64. Montevideo.

https://ucu.edu.uy/sites/default/files/facultad/fce/rso/cuadernos-de-rso-vol-4-n1-chumaceiro.pdf

Elssy Bonilla-Castro, and Rodriguez, Penelope (2005). Above and beyond the dilemma of the methods. Grupo Editorial Norma. Universidad de Los Andes. pp. 18-401. Bogota. Colombia.

François Vallaeys, (2016). Introduction to University Social Responsibility RSU Editions University Simon Bolivar, 175 p. ISBN: $978-$ 958-8930-65-7. Barranquilla. https://hdl.handle.net/20.500.12442/3544

Garcia, Fernando. (2000). An approach to the concept of relevant university. Magazine Compendium. No. 5. University Western Center Lisandro Alvarado. Barquisimeto. https://dialnet.unirioja.es/ejemplar/221144

Girdzijauskaite, E., Radzeviciene, A., Jakubavicius, A. (2019). Impact of international branch campus KPIs on the university competitiveness: FARE method. Insights into Regional Development, 1(2), 171-180. https://doi.org/10.9770/ird.2019.1.2(7)

Glaser, B. (1992). Basic of Grounded Theory Analysis: Emergence vs. Forcing. Mill Valley: C. A. Sociology Press.

Guardian-Fernández, Alicia (2007). The qualitative paradigm in the Investigation Socio-Educativa. CECC. Costa Rica. 


\section{ENTREPRENEURSHIP AND SUSTAINABILITY ISSUES}

ISSN 2345-0282 (online) http://jssidoi.org/jesi/

2020 Volume 7 Number 4 (June)

http://doi.org/10.9770/jesi.2020.7.4(26)

Largacha-Martinez, Carlos, Pinzón, Adela Johanna, León Velásquez, Elizabeth. (2015). The merger of the humanist management and organizational learning produce sustainable organizations and centers of excellence. Magazine School of Business Administration. Available at: https://www.redalyc.org/articulo.oa?id=20640430006 https://doi.org/10.21158/01208160.n78.2015.1191

Marin, Katiuska and Atencio, Edith, Hernandez de Velazco, Judith. (2009). Networks of innovation for the endogenous development: a case study. Management Training 8 Year magazine, 1, 71-98. https://produccioncientificaluz.org/index.php/rafg/article/view/794/796

Martinez -Usarralde, María-Jesus, \& L toLoret-Catal, Carmen, \& Mas-Gil, Sara (2017). University Social Responsibility (RSU): Principles for a Sustainable University, cooperative and Democratic from the participatory diagnosis of its students. Education Policy Analysis Archives/Analytical Files of Educational Policies, 25, 1-22. Arizona. https://www.redalyc.org/articulo.0a?id=2750/275050047060

Mutalimov, V., Kovaleva, I., Ulitina Katerina, A., \& Stepanova, D. (2020). Methodology comprehensive assessment of the business environment in the regions of Russia: Introducing business environment into the education system. Journal of Entrepreneurship Education, 23(1). https://www.abacademies.org/articles/Methodology-comprehensive-assessment-of-the-business-environment-1528-2651-23-1512.pdf

Of Ketele, Jean-Marie. (2008). The social relevance of higher education. GUNI, pp. 55-59.

https://upcommons.upc.edu/bitstream/handle/2099/7946/04\%20\%2855-61\%29.pdf?sequence=1\&isAllowed=y

Palomino, B., and Lopez, G. (2019). Social Responsibility of ecotourism enterprises, regulatory and public policy in Mexico City. 15 LEGAL CUC, (1), 353-382. https://dx.doi.org/10.17981/juridcuc.15.1.2019.14

Paz Marcano, A., Sierra Daza, L., \& López Juvinao, D. (2019). Social Responsibility: Sustainable dimension towards the environment of coal companies in Colombia and Venezuela. ECONÓMICAS CUC, 40(1). https://doi.org/10.17981/econcuc.40.1.2019.03

Pereira, M. (2016). Toward the construction of the right environmental energy as a discipline. 12 Legal CUC, (1), 177-204. https://dx.doi.org/10.17981/juridcuc.12.1.2016.10

Sachs, Jeffrey (2015). The era of sustainable development. Ediciones Deusto. Barcelona

Sotolongo, Luis Delgado, Jesus. (2006). The contemporary revolution of knowledge and the social complexity: toward a new type of social sciences. The Latin American Council of Social Sciences - CLACSO. ISBN 987-1183-33-X 1. Buenos Aires. 224 p.

UNESCO United Nations Educational, Scientific, and Cultural Organization (2009). Report by the Institute for Statistics of the Organization.

UNESCO. United Nations Organization for Education and Culture (1998). Higher education in the 21st century. Vision and Action. Summary of the World Declaration on Higher Education. Paris.

United Nations (2019). Report of the objectives of sustainable development. New York.

Vallaeys, F. (2018). The ten fallacies of University Social Responsibility. RIDU, 12(1), 34-50. Lima. http://dx.doi.org/10.19083/ridu.12.716

Vázquez-Barquero, Antonio. (1999). Development, networks and innovation. Lessons on endogenous development. Editorial Pyramid.

Voronkova, O. Y., Melnik, M. V., Nikitochkina, Y. V., Tchuykova, N. M., Davidyants, M.A., Titova, S. V. (2020). Corporate social responsibility of business as a factor of regional development. Entrepreneurship and Sustainability Issues, 7(3), $2170-2180$.

https://doi.org/10.9770/jesi.2020.7.3(47)

World Commission on Environment and Development: The Brundtland Commission (1987). Our common future. Oxford: Oxford University Press. 


\section{ENTREPRENEURSHIP AND SUSTAINABILITY ISSUES}

ISSN 2345-0282 (online) http://jssidoi.org/jesi/

2020 Volume 7 Number 4 (June)

http://doi.org/10.9770/jesi.2020.7.4(26)

Judith Josefina HERNÁNDEZ DE VELAZCO

ORCHID ID: http://orcid.org/0000-0002-5621-9496

Rafael RAVINA RIPOLL

ORCHID ID: http://orcid.org/0000-0001-7007-3123

Ana Cecilia CHUMACEIRO HERNANDEZ

ORCHID ID: http://orcid.org/0000-0002-8539-2853

Register for an ORCID ID:

https://orcid.org/register

Copyright (C) 2020 by author(s) and VsI Entrepreneurship and Sustainability Center

This work is licensed under the Creative Commons Attribution International License (CC BY).

http://creativecommons.org/licenses/by/4.0/

(c) (†) Open Access 